\title{
The Significance of Caspian Oil and Gas for Diversifying Energy Imports to the Visegrad Group Countries
}

\author{
Jacek Cichocki ${ }^{1}$
}

Since the break-up of the USSR, when the first Western oil concerns appeared in the Caspian Sea region (first in Azerbaijan, then in Kazakhstan), a discussion has been going on about the significance of Caspian oil and gas. The primary issue is the diversification of energy import sources to Europe. West European countries perceive increasing their supplies from the Caspian region as a way to lessen their dependence on oil coming from OPEC-associated countries, especially the Persian Gulf. For Central Europe, and for the Visegrad Group countries in particular, ${ }^{2}$ Caspian energy resources may become a potential alternative to the oil imported from (or transported through) Russia that currently satisfies most of the demand in these countries. At the moment, the majority of the existing transport routes for Caspian oil run through the territory of the Russian Federation. Consequently, Russia effectively controls supplies of Caspian oil to Central Europe, and is able to influence its price. Such a situation means that, in the future, Caspian oil supplied to the Visegrad Group countries will not ensure a fully diversified set of imported supplies, as required by the European Union. True diversification could only be achieved if the already existing pipelines-Baku-Supsa and Odessa-Brody-were used for transporting Caspian oil to the Central European markets. But there are a number of problems here.

\section{Visegrad Group energy demands and dependence on Russian oil exports}

Currently, the Visegrad Group countries consume around 38 million tonnes of oil and oil-related products annually. ${ }^{3}$ Out of this quantity, around 85 percent is met by oil imports from the Russian Federation. The country most heavily dependent on Russian supplies is Slovakia; Russian oil supplies meet 100 percent of Slovakia's oil demand, including the demand of the Slovakian petrochemical industry (around 5.3 million tonnes in total annually). ${ }^{4}$ The import of Russian oil also satisfies 80 percent of the demand of Poland and Hungary (around 16.6 million tonnes and 5.8 million tonnes respectively). ${ }^{5}$ The Czech Republic imports in relative terms the least oil from Russia, around 65 percent (5.2 million tonnes). ${ }^{6}$ Such a situation is at variance with the EU guidelines for power engineering pol-

\footnotetext{
${ }^{1}$ Jacek Cichoski is acting director of the Centre for Eastern Studies in Warsaw, Poland.

2 The Visegrad Group countries are: Poland, Czech Republic, Slovakia, and Hungary.

${ }^{3}$ Oil Information 2001, International Energy Agency (Paris: OECD, 2001); data for 2000.

${ }^{4}$ Ibid.

${ }^{5}$ Ibid.

${ }^{6}$ Ibid.
} 


\section{THE QUARTERLY JOURNAL}

icy, which requires that the member states should limit their dependence on the import of power engineering raw materials from a single country or region, to one-third of their total demand. That is why the Visegrad Group countries, which aspire to join the European Union, are looking for an opportunity to diversify their oil supplies.

This is not an easy process. There are a number of factors supporting the widest possible utilization of the Russian oil by Eastern European countries. One of the most important is its attractive price; a barrel of Russian oil is a few dollars cheaper than a barrel of oil from other regions. ${ }^{7}$ Besides, the links among Slovakia, the Czech Republic, Hungary, and Poland, a legacy of the time when these countries constituted a common economic system with the USSR, are of crucial importance. The "Friendship" pipeline system, still in operation, makes a convenient route for oil import from the East. Large parts of the petrochemical infrastructure in the Visegrad Group countries are prepared to process Russian oil, which is characterized by a specific chemical composition. Russian concerns are also trying to maintain their dominant position among importers in the Central European market. The largest ones, Lukoil and Yukos, continue to invest in the region, and they actively participate in the privatization of local oil companies. Russia invests in oil business in the Visegrad Group countries not only because these countries are important markets (about 25 percent of total oil export from Russia goes outside the Commonwealth of Independent States) ${ }^{8}$, but also because they constitute a transit region. An important Russian oil transport route to the Western European market—-the aforementioned "Friendship" pipeline—runs through that region.

Despite these relationships, the Visegrad countries are considering possible methods of oil import diversification in order to become less dependent on Russian raw material. This is why for the last few years the authorities in these countries have been more and more interested in power engineering resources from the Caspian Sea region.

\section{Caspian oil resources}

According to the estimates of an American Energy Information Administration, there are currently around 4.8 billion tonnes of confirmed oil resources in the Caspian Sea region. It is also estimated that this quantity may rise even to around 37 billion tonnes as a result of deposits that have not been probed yet. ${ }^{9}$ The largest deposits are located in the territory of western Kazakhstan and in the Kazakh part of the Caspian Sea shelf. Presently the production of oil in the region, particularly in Kazakhstan and Azerbaijan, amounts to around 56 million tonnes annually. ${ }^{10}$

\footnotetext{
${ }^{7}$ FSU Energy 7:12 (March 29, 2002).

${ }^{8}$ Goskomstat (Russian Statistical Yearbook), 2001.

${ }^{9}$ EIA website, at www.eia.gov.pl

${ }^{10}$ Ibid.
} 
Nearly 70 percent of the oil extracted in the region goes for export, mainly to Russia. The EIA experts estimate that by 2010 the production of oil in the region will have increased by more than three times, and due to a minute rise in domestic consumption most of the raw material will continue to be exported. Regardless of how precise these estimates are, we can assume that the Caspian region is the location of important oil resources (they are important particularly from the point of view of European oil resources), and in the coming years the volume of oil production and export will be large enough to meet the prospective demand of the Visegrad Group countries (the demand following from the need to diversify their import). In this context the main problem for the future is the development of a transport route to Central Europe that would transport Caspian oil independent from the Russian pipeline systems.

\section{Possible transport routes for Caspian oil and the problem of import diversi- fication in the Visegrad Group countries}

At present, the oil from the Caspian basin is exported through three main routes:

- The Atyral (Kazakhstan)-Samara (Russia) pipeline, built in the Soviet era and recently modernized, so that its transport capacities allow for the export of 15 million tonnes annually. On the territory of the Russian Federation the pipeline joins the Russian pipeline system, enabling the transport of oil through the "Friendship" system farther to the West, or to oil terminals on the Baltic coast, in Russian Primorsk and in the Baltic States.

- A new pipeline, from Tengiz, Kazakhstan to Novorossiysk, a Russian terminal on the Black Sea, which started to operate in autumn 2001, with current capacity of around 30 million tonnes annually and a target capacity of 60 million tonnes. Novorossiysk is also a destination for Azerbaijani oil, coming through the Baku pipeline. From Novorossiysk the raw material is presently transported on tankers across the Black Sea and through the Turkish straits of Bosphorus and Dardanelle to the Mediterranean Sea and later to oil terminals in northwestern Europe.

- A small new pipeline, from Baku, Azerbaijan, to Supsa, a Georgian oil terminal on the Black Sea, running through the Southern Caucasus, which started to operate in 1999 and has a capacity of around 5 million tonnes annually. There is a railway line running parallel to the pipeline route, which is also used to transport oil from Baku to Batumi (a Georgian railway terminal on the Black Sea). The oil from both terminals is transported on tankers through the Turkish straits to Western Europe, and to other Black Sea terminals, such as Odessa. 


\section{THE QUARTERLY JOURNAL}

The first two routes are used to export oil extracted in Kazakhstan. The Russian terminal in Novorossiysk is also a destination for oil from Azerbaijan and from the Russian deposits in Siberia. The third route is the export route for Azerbaijani oil, and the railway line transports some quantities of this raw material from Kazakhstan. The third oil transport route is the only one that does not run through Russian territory. Its basic shortcoming is, however, a low transmission capacity in comparison to the other two routes.

There are plans to build a new pipeline in the coming years, with a capacity of around 50 million tonnes annually, from Baku, via Georgia, to Ceyhan, a Turkish terminal on the Mediterranean. From there the Caspian oil is to be transported on tankers to European terminals and even to the American market. A consortium led by BP Amoco projects the beginning of work on this investment for spring 2003. The project is strongly supported by the U.S. administration and that is why, despite high costs and many difficulties, it is likely to be implemented.

A review of the existing and prospective routes for the transport of Caspian oil to the European markets shows that only one of them may ensure a true diversification of oil imports for the Visegrad Group countries and the actual lessening of their dependence on Russian raw material. It may also help lessen their dependence on the pipelines running through the territory of the Russian Federation. This route would transport Caspian oil through the Southern Caucasus to Georgian terminals and then on tankers to the terminals on the western shore of the Black Sea. Presently the most attractive one is the newly built terminal in Odessa, from where the oil may by transported farther by a new pipeline, joining Odessa with the southern branch of the "Friendship" pipeline in Brody, in the western Ukraine. From Brody, the Caspian oil could go to Slovakia through the "Friendship" system, and on to Hungary and the Czech Republic. There is also a plan to extend the Brody pipeline to Poland and join it with the Polish system, which would enable the transport of this oil to the north, to the oil terminal in Gdansk.

The construction of the Odessa-Brody terminal and pipeline has already been completed. It will have a capacity of 12 million tonnes annually, with a target capacity of around 40 million tonnes. The pipeline is currently being prepared for operation. But if the described variant is to be implemented, and if the four Visegrad countries are to receive 10-15 million tonnes of oil annually, which is necessary for the desired level of import diversification, two conditions have to be met:

- The Ukrainian side should change the rules of managing the Odessa-Brody pipeline, making them more commercial in orientation, and they should involve Western concerns dealing with oil extraction in the Caspian region in this investment, as well as companies that could provide markets for oil in Europe; 
- The Baku-Supsa pipeline should not only retain its current transmission capacities but it should also try to enhance them. This, however, might prove difficult due to the construction of a large Baku-Ceyhan pipeline in the region.

Of course, the cost of oil transport is not a moot point; due to the necessity to reload the oil to and from tankers, the cost for these routes will not be low, and it might prove less competitive than the cost of transport through the northern route, through Russia. In the case of the Czech Republic, Hungary, and Slovakia, with their inland location, the costs associated with this route will undoubtedly be competitive with those of the Baku-Ceyhan pipeline, which would route oil to tankers in the Mediterranean, to oil terminals in Western Europe, and again through pipelines to Central Europe. (Poland is in a different situation because it has a northern coastal terminal in Gdansk).

Although Caspian oil could potentially become an important element of import diversification for power engineering materials in the Visegrad Group countries, the limitations related to its transport have put this prospect on the back burner. For an independent oil transport route to Central Europe to be used, a compromise solution from the Ukrainian authorities and the involvement of the Western concerns operating in the Caspian region is required. One could predict, however, that in the coming years larger and larger quantities of the Caspian oil, particularly from Kazakhstan, will be coming to the four Visegrad countries through the territory of the Russian Federation via pipelines and railways. In the end, it is worth while to highlight the fact that activities to pursue oil import diversification that are undertaken by countries from the Visegrad Group are primarily motivated by their attempts to join EU. The intensity of these diversification activities is largely dependant on future EU energy policy, and on Brussels' determination in executing its rules. 


\section{Bibliography}

Oil Information 2001. Paris: OECD, International Energy Agency, 2001. 